Témoigner Témoigner. Entre histoire et mémoire

Getuigen Revue pluridisciplinaire de la Fondation Auschwitz

$115 \mid 2013$

L'Espagne en construction mémorielle

\title{
Het virtuele in de herinnering
}

Du virtuel dans la mémoire

The Virtual in Memory

Philippe Mesnard

Traducteur : Stijn Verleyen

\section{(2) OpenEdition}

Journals

\section{Édition électronique}

URL : http://journals.openedition.org/temoigner/508

DOI : 10.4000/temoigner.508

ISSN : 2506-6390

Éditeur :

Éditions du Centre d'études et de documentation Mémoire d'Auschwitz, Éditions Kimé

\section{Édition imprimée}

Date de publication : 1 mars 2013

Pagination : 7

ISBN : 978-2-84174-628-6

ISSN : 2031-4183

Référence électronique

Philippe Mesnard, « Het virtuele in de herinnering », Témoigner. Entre histoire et mémoire [Online], 115 |

2013, Online op 01 juin 2015, geraadpleegd op 23 octobre 2020. URL : http://journals.openedition.org/ temoigner/508 ; DOl : https://doi.org/10.4000/temoigner.508 


\section{Het virtuele in de herinnering}

Sinds enkele jaren ziet men een steeds grotere aanwezigheid van technologische snufjes op herinneringssites. Vraag is of deze evolutie ethische gevolgen kan hebben voor de overlevering. Musea hebben hun aanzien immers grondig gewijzigd onder impuls van tendensen die door artiesten werden ingezet eind de jaren 1980. Daarna was het de beurt aan de architecten om de vertaalslag te maken naar het patrimonium binnen de stedelijke ruimte. Het hoeft geen betoog dat de herinnering steeds nadrukkelijker aanwezig is in vormen van gemeenschapsleven, net zoals het duidelijk is dat deze ontwikkeling samenvalt in de tijd met die van web-gebaseerde technologieën. Het verbaast dan ook niet dat herinnering en technologie elkaar gevonden hebben en tegenwoordig met elkaar gecombineerd worden. Daar komt nog bij dat de bezoekersaantallen een ongeziene stijging gekend hebben; deze bezoekersstromen moeten opgevangen worden met een sterk ontwikkelde infrastructuur, ondersteund door de nieuwe technologieën.

Zo hebben hele steden een specifiek en georganiseerd herinneringskarakter verworven, via uitgestippelde wandelingen, evenementen, stations en etalages. Wanneer men in Berlijn met een audiogids rondloopt ontdekt men een aantal plaatsen zoals het kasteel van Charlottenburg, de Siegessäule (overwinningszuil opgericht na de oorlog van 1870), de Fernsehturm (televisietoren die destijds boven de muur uittorende om de Westerlingen te jennen), maar ook het Holocaustmemoriaal of de Berlijnse Muur. In Warschau kan men de Chopin-wandeling volgen door de QR-codes (of tags) te scannen die op marmeren banken gegraveerd staan; men ontdekt zo de plaatsen die de componist dierbaar waren, om uiteindelijk uit te komen bij het monument voor de opstand in de herfst van 1944. Nog een andere mogelijkheid om herinneringssites en internettechnologie te verbinden bestaat erin een gegidste wandeling door een concentratiekamp te downloaden op een smartphone, zodat men in het kamp kan rondwandelen onder de virtuele begeleiding van een overlevende, die getuigt over wat hij/zij er heeft meegemaakt. Recent hebben de Territoires de la mémoire uit Luik dit interessante initiatief genomen voor het kamp van Mauthausen, en het is wellicht maar een kwestie van tijd eer het herinneringscomplex van Auschwitz (Auschwitz I en Auschwitz-Birkenau) gelijkaardige snufjes opzet op de gepaste schaal en op maat van zijn publiek. Zo wordt men er toe gebracht om op een intuïtieve manier deze plaatsen van terreur te ontdekken, waar men zonet door een overlevende werd rondgeleid, en waar destijds mensen de dood vonden.

Zulks kan zeker een manier zijn om historische kennis, getuigenissen en burgerzin over te brengen bij een nieuw doelpubliek : men laat hen deel hebben aan de beleving van de plaats zelf, en men trekt hun aandacht via het technologisch medium waarmee ze zo vertrouwd zijn. Maar het technologische aspect mag niet met het ethische verward worden, en kan dat laatste in geen geval aflossen of vervangen. De indruk kan immers gewekt worden dat alles uiteindelijk maar één klik verwijderd is, en dat het probleem van de overlevering verholpen wordt met deze vastgelegde parcours van de herinnering - de indruk, met andere woorden, dat de technologie een antwoord is, terwijl het slechts om een middel gaat.

Prof. Dr. Philippe Mesnard, Hoofdredacteur

Vertaling uit het Frans door Stijn Verleyen 